\title{
Determinants of Watching a Film: A Case Study on Dhallywood Film Industry, Bangladesh
}

\author{
Mst. Farjana Easmin ${ }^{1}$, Afjal Hossain ${ }^{2 *}$, Anup Kumar Mandal ${ }^{3}$ \\ ${ }^{1}$ Lecturer, Department of History, Shahid Ziaur Rahman Degree College, Shaheberhat, Barisal, BANGLADESH \\ ${ }^{2}$ Associate Professor, Department of Marketing, Patuakhali Science and Technology University, Dumki, Patuakhali-8602, BANGLADESH \\ ${ }^{3}$ Assistant Professor, Department of Economics and Sociology, Patuakhali Science and Technology University, Dumki, Patuakhali-8602, \\ BANGLADESH
}

*E-mail for correspondence: hossainafjal@gmail.com

https://doi.org/10.18034/abr.v8i3.164

\begin{abstract}
The purpose of the study is to classify the different factors influencing the success of a Bengali film, and in this regard, a total sample of 296 respondents has been interviewed through a structured questionnaire. To test the study, Pearson's product moment correlation, ANOVA and KMO statistic has been used and factor analysis is used to group the factors needed to develop for producing a successful film. The study reveals that the first factor (named convenient factor) is the most important factor for producing a film as well as to grab the attention of the audiences by $92 \%$ and competitive advantage by $71 \%$, uniqueness by $81 \%$, supports by $64 \%$, features by $53 \%$, quality of the film by $77 \%$ are next consideration consecutively according to the general people perception. The implication of the study is that the film makers and promoters should consider the factors properly for watching more films of the Dhallywood industry in relation to the foreign films especially Hindi, Tamil and English. The government can also take the initiative for the betterment of the industry through proper governance and subsidize if possible.
\end{abstract}

Key words: Dhallywood, Film Industry, KMO Statistics, Success Factors, Bangladesh

\section{INTRODUCTION}

Bangladesh is a country of Muslims, Hindus, Christians, Buddhists and some Minorities Tribes. Every Tribe, Clans maintain all the cultures of Bangladesh in their way. Movie is one of the entertainments which reflect their own culture and norms. Unfortunately, the dish media is a sector where most of the foreign channels dominate the Bangladeshi viewers. While enjoying different TV shows of other country's rather than Bangladesh; Bangladeshis are incorporating some nasty foreign cultures in their trends which are drastically ruining of its own cultures. Several TV shows where women wear a very short dress which doesn't match with the Bangladeshi culture but unfortunately Bangladeshi people are following it. So, not only the producer or director but also the actor (actress) didn't care about this subject matter. Cinema has a great source of entertainment for every people of Bangladesh. Maximum people spend their leisure period watching cinema. The requirements for a good film are-a good story, acting, hero and heroine, sound, location, song, camera, light and many other things. A good film reflects a nation even it can act as a mirror of a country. A success film can teach us many valuable aspects and influence the whole of a society. In Bangladesh, the major cause behind the failure of a film is using overpower of director and producer because they cannot accumulate all elements of the film. The producers are not conscious of their viewer's choice. Bangla cinema refers to the Bengali Language filmmaking industries in the Bengal region of South Asia. There are two major film-making hubs in the region: one in Kolkata, West Bengal, India (Indian Cinema) sometimes called Tollywood (a portmanteau of the words Tollygunge and Hollywood) and the other in Dhaka, Bangladesh (Bangladeshi Cinema) sometimes called Dhallywood (a portmanteau of the words Dhaka and Hollywood). The history of Bengali cinema dates back to the 1890s when the first "Bioscopes" were shown in theatres in Kolkata. Within a decade, the first seed of the industry was shown by Hiralal Sen in Bhola-a sub-district town in Southern Bangladesh, considered a stalwart of Victorian era cinema when he set up the Royal Bioscope Company. 
The years between 1898 and 1955 remain unexplored to date, but it is a period full of "great man" and their achievements for the development of Bangladeshi film. Similar to, much of Asia, silent film production began in the then Bengal (East Pakistan) during the 1900s and sound film production in the 1950s. It is noteworthy that the film theatres started to be built in the 1910s but the production of theatrical features started as late as the mid1950s. Picture House, the first permanent cinema in Dhaka began its operation during the year between 1913-1914. The cinema was renamed to New Picture House later and then again rename to Shabistan. Dhirendra Nath Ganguly (known as D.G) established the first Bengali owned Production Company named Indo British Film Company (IBFC) in 1918 after Sen's works. The IBFC produce its first film "Bilat Ferat" in 1921. A total number of 80 cinemas were found in listed by 1947 what is now in Bangladesh. Feature films were also made in Bengali as early as 1919 by Bilwa Mangal but most of its production was done in Calcutta. The Nawab family of Dhaka for the first time produced Sukumari between the year 1928-1929 and The Last Kiss in the year of 1931. After the partition of India in 1947, Mohammad Ali Jinnah visited the film industry and the first film was made in East Pakistan. The first film was produced in 1948 by the radio broadcaster Nazir Ahmed. Mukh O Mukhosh, the first full-length feature film with sound was made in East Pakistan produced by Abdul Jabbar Khan and released on August 3, 1956. It was served as the central motivation to the setting up of a local film production industry in the then East Pakistan. The interesting thing is that Editing, Printing, and all other film processing for this movie was done in Lahore, Pakistan. One can say that this half-century is the period when film was assimilated in the then East Bengali cultural environment. The local film production industry was founded in the then East Pakistan as late as the late 1950s. The second East Bengali sound feature film, The Sky and The Earth "Akash Ar Mati" was released in 1959 in Dhaka by Fateh Lohani. There were no other films released in the next three years. During 1957/58, the first full-service film production studio, East Pakistan Film Development Corporation (EPFDC now BFDC) was established in Dhaka. Bangabandhu Sheikh Mujibur Rahman, The Father of Bengali Nation, the then industries minister of East Pakistan in the United Front Cabinet, introduced the necessary bill in the parliament. Notable historians of Bangladesh cinema, including Zahir Raihan, Khan Ataur Rahman, Salahuddin, Alamgir Kabir, Amjad Hossain, Mohiuddin Shaker, Sheikh Niyamat Ali, Humayun Ahmed, Morshedul Islam, Tanvir Mokammel, Tareque Masud, Salauddin Lavlu and Enamul Karim Nirjhar are the prominent directors. Another internationally acclaimed filmmaker from Bangladesh is Morshedul Islam who won major awards at the International Film Festival Mannheim-Heidelberg and other international film festivals. Hayat (1987), Mutsuddi (1987), Quader (1993) and Zaki (1997) term this film as the "first" film (theatrical feature) produced in the then East Pakistan/ East Bengal. There were also less-celebrated "beginnings" of cinema in Bangladesh in the early decades of the twentieth century.

The Bangladeshi film industry means the films produced in Dhaka. It produced approximately 80 movies each year in between the year 1996-2003 (Raju, 2011) which is decreased to 35-40 in recent years (Yeasmin, 2011). The number of film production has been reduced to only 30 in 2013 (Daily Prothom Alo, 2013). The average movie budget was about BDT (Bangladeshi Taka) 12 crores. Islam (2008) stated that Bangladeshi film was passing through a crisis. It has gone backward, and its productions have declined in quality. The similar result found in the study of Ahmed (2010). But he didn't state the different reasons for which the film is not successive in the market. Although the majority of the films made in Bangladesh are strictly commercial, a handful of directors from Bangladesh have attained critical acclaim for their outstanding work. But, the high-risk, high-profit and quick-production orientation of the popular film industry in contemporary Bangladesh produces several kinds of film texts that directly serve the nationalist rhetoric of the State and the local film-capitalists (Raju, 2012). He stated that the production of the film is not a problem in his study, but the problem is about the quality of the film. The problem of the study is that he didn't mention the attributes related to the quality of a film. The feature of the films that have to consider in his study didn't narrate.

Lovelock et al. (2013) found that customers mainly search for some tangible benefits while they are watching films in the cinema hall. Masud (2012) stated that poor environment of the cinema halls is the failure of a film. It is evident that the number of cinema halls has been decreased from 1230 to 742 from the year 1990 to 2010 (Daily Prothom Alo, 2013). The humor is usually laced with crudities; the heroes are archetypal macho men, and their glycerin-eyed heroines usually come from the bottom of the pile in Dhaka. But local technicians and workers are not convinced (Biswas, 2013) about the performance of the celebrities. Masud (2011) stated that over taxation in cinema ticket is another barrier to produce a film. Though movies can be enjoyed in various media's small screen i.e. TV, online, DVD player etc. but the people of USA and European countries are still going to the cinema halls (Yeasmin, 2011). Masud (2012) stated that Bangladesh shopping complex are replacing the cinema halls where in India and Pakistan, every shopping complex includes multiplex cinema hall. In this study, the different determinants for the successive film industry have been discussed very carefully.

Bangladeshi cinema mainly appropriated and localized film plots and other elements from Calcutta cinema which was began in the 1950s. The film industry in Dhaka somewhat positioned itself as the base for a BengaliMuslim cinema from the 1960s and onwards (Raju, 2011). 
In most of the films of Bangladesh are not produced with the consideration of the international spots even the support services are not well-furnished that' why the problems arise every time to do business. In his study, the subject matter of the other things; competition, the usages of the different culture is not considered properly. The important thing is most of the films in the earlier ages were produced considering the local scenario and spots with traditional film making process. This lacks the usages of modern equipment, the different factors turns to a successful film ever. In this study, the recommendations are suggested according to the viewers' perception currently on the market. Since the literature are not available regarding this issue, that's why this study is completed according to the market survey of the film industry in Bangladesh. With the above facets and the present produced films in Bangladesh, the following objectives are identified for this study:

- Find out the current status of the film industry in Bangladesh

- To categorize the different factors according to the importance of the Bangladeshi Film

- To make some recommendations for the well-being of the film industry in Bangladesh

\section{Materials AND Methods}

This study is based on two-stage research. In the first stage, exploratory research is conducted to identify the factors determining the viewers' perception. A total of 296 respondents are interviewed through a structured questionnaire from July 2013 to April 2015 of which 123 are workers, 43 are students, 50 are government service holders and housewives equally, 15 are rickshaw pullers, 12 are teachers, 10 are businessmen, 9 are engineers, 24 are doctors, carpenters, farmers, and bankers equally, 4 are drivers, and 6 are members of the village and hawkers equally.

Table 1: Variables considered for this study

\begin{tabular}{|c|c|}
\hline $\begin{array}{l}\text { 1. Duration of the Film } \\
\text { 2. Story of the Film } \\
\text { 3. Dialogue of the Film } \\
\text { 4. Resolution of the Film } \\
\text { 5. Actor / Actress of the Film } \\
\text { 6. Song of the Film } \\
\text { 7. Action of the Film } \\
\text { 8. Language of the Film } \\
\text { 9. Sensor board } \\
\text { 10. Where do you see film }\end{array}$ & $\begin{array}{l}\text { 11. Internal environment of } \\
\text { the cinema hall } \\
\text { 12. Competition of film } \\
\text { industry } \\
\text { 13. Imitation of the film } \\
\text { 14. Relevancy of the reality of } \\
\text { the film } \\
\text { 15. Educational value from } \\
\text { the film } \\
\text { 16. Sound and song selection } \\
\text { of the film } \\
\text { 17. Selection of the place or } \\
\text { location of the film } \\
\text { 18. Investigation of the } \\
\text { government }\end{array}$ \\
\hline
\end{tabular}

Respondents were selected from Barisal District (50), Patuakhali (146) District (Dumki Upazila, Lebukhali Upazila), Dhaka division (50) and Shariatpur District (50). The structured questionnaire was designed with the help of a 5-point Likert scale where 1=strongly disagree, $2=$ disagree, $3=$ moderate, $4=$ agree, and $5=$ strongly agree. Then descriptive research was conducted for understanding general people perception about the film industry of Bangladesh. The manuscript was prepared basically with the help of field survey data because of the lack of sufficient secondary data. Some literature has been collection from some journals and websites. To test the result, Pearson's product moment correlation, ANOVA and KMO statistics were used. To identify some important factors and for grouping, the factors according to their importance factor analysis were used in this study. The statistical computer package SPSS version 14.0 is used to analyze the data.

\section{Model Designed}

To determine the factor score for the ith factor with the help of the model: $\mathrm{F}_{\mathrm{i}}=\mathrm{W}_{\mathrm{i} 1} \mathrm{X}_{1}+\mathrm{W}_{\mathrm{i} 2} \mathrm{X}_{2}+\mathrm{W}_{\mathrm{i} 3} \mathrm{X}_{3}+---+\mathrm{W}_{\mathrm{i} 18} \mathrm{X}_{18}$ Where $F_{i}$ is an estimate of the ith factor, $W_{i}$ is weight or factor score coefficient, and $\mathrm{k}$ is a number of variables. According to the model, it is possible to select weights or factor score coefficients so that the first factor explains the portion of the total variance. Then the second set of weights can be selected so that the second factor accounts for most of the residual variance subject to being uncorrelated with the first factor. The stated principle could be applied to select additional weights for the additional factors.

\section{Discussion AND Data AnALYsis}

\section{Validity Test}

Table 2: Pearson's Product Moment Correlation and Regression Analysis

\begin{tabular}{|c|c|c|c|c|}
\hline Model & R & R Square & Adjusted R Square & $\begin{array}{c}\text { Std. Error of } \\
\text { the Estimate }\end{array}$ \\
\hline 1 & 0.959 & 0.920 & 0.915 & 0.353 \\
\hline
\end{tabular}

The Pearson's Product Moment Correlation value, $\mathrm{r}=$ $0.959>0.50$ which means there is highly correlation between the variables and adjusted $\mathrm{R}$ square is 0.920 (Table 2) which denotes that about $93 \%$ variation of the dependent variable is explained by independent variables included in this model.

Table 3: ANOVA Test

\begin{tabular}{|c|c|c|c|c|c|c|}
\hline Model & & Sum of Squares & df & Mean Square & F & Sig. \\
\hline \multirow{3}{*}{1} & Regression & 398.861 & 17 & 23.462 & 188.594 & $0.000(\mathrm{a})$ \\
\cline { 2 - 7 } & Residual & 34.585 & 278 & 0.124 & & \\
\cline { 2 - 7 } & Total & 433.446 & 295 & & & \\
\hline
\end{tabular}

Table 3 illustrates one way variable test of the study. It is depicted from the table that value (critical value) of F-statistic is 1.96 with $(17 \times 278)$ degrees of freedom which is less than the calculated value 188.594 means null hypothesis is rejected at $5 \%$ level of significance. The F-statistic is 2.25 with $(17 \mathrm{x}$ 278) degrees of freedom which is also less than the calculated value 188.594 means null hypothesis is rejected at $1 \%$ significance level. It also means that there is a significant 
correlation between the studied dependent variable and independent variables. It means that there is a relationship between the dependent and independent variables which have been studied. So, we can say that the researchers studied the variable are very coherent.

Table 4: KMO and Bartlett's Test

\begin{tabular}{|c|c|c|}
\hline \multicolumn{2}{|c|}{$\begin{array}{c}\text { Kaiser-Meyer-Olkin Measure } \\
\text { of Sampling Adequacy. }\end{array}$} & 0.523 \\
\hline \multirow{2}{*}{$\begin{array}{c}\text { Bartlett's Test } \\
\text { of Sphericity }\end{array}$} & Approx. Chi-Square & 3383.547 \\
\cline { 2 - 3 } & Df & 153 \\
\cline { 2 - 3 } & Sig. & 0.000 \\
\hline
\end{tabular}

Table 4 illustrates the factor analysis of 18 variables with 296 samples is found adequate (KMO test result $=0.523 \geq$ 0.5 ) and valid (Bartlett's test of sphericity indicates a significance level of 0.000).

\section{Determination of the Factor}

Table 5: Eigenvalue, Relative Variance (\%) and Cumulative Relative Variance (\%) of the Factors

\begin{tabular}{|c|c|c|c|}
\hline \multirow{2}{*}{ Component } & \multicolumn{3}{|c|}{ Initial Eigenvalues } \\
\cline { 2 - 4 } & Total & \% of Variance & Cumulative \% \\
\hline 1 & 3.417 & 18.985 & 18.985 \\
\hline 2 & 2.800 & 15.555 & 34.540 \\
\hline 3 & 2.090 & 11.609 & 46.149 \\
\hline 4 & 1.704 & 9.465 & 55.614 \\
\hline 5 & 1.265 & 7.029 & 62.644 \\
\hline 6 & 1.089 & 6.051 & 68.694 \\
\hline
\end{tabular}

Extraction Method: Principal Component Analysis.

The factor analysis shows that to be a successful film in the market, the people associated with the film industry have to stress on the following six (6) factors with an eigenvalue greater than one (Table 5). These six factors are identified out of 18 variables explain $68.694 \%$ variability of the data.
Also it can be noted that the first and most important factor (convenient factor) appears to be the most important as it explains $18.985 \%$ ( $\sigma 2)$ of the variability and the other factors are competitive advantage factor, unique factor, support factor, feature factor and quality factor $(\sigma 2$ $=15.555 \%, 11.609 \%, 9.465 \%, 7.029 \%$ and $6.051 \%$ ). The communalities of the variables that constituted the factors are found very strong which indicates robust relationships between the variables (Appendix).

Table 6 shows the individual variable is used to constitute a factor from the component matrix. Since the component matrix doesn't make any meaning to constitute the factors that's why rotated component matrix is used to form the factors which are shown in Table 7 . The different factors constituted the variables are as follows:

\begin{tabular}{|c|c|}
\hline Factor Name & Variables \\
\hline $\begin{array}{l}\text { First Factor } \\
\text { (Convenient) }\end{array}$ & $\begin{array}{l}\text { 1. Competition of the Film Industry } \\
\text { 2. Location Selection of the Film }\end{array}$ \\
\hline $\begin{array}{l}\text { Second Factor } \\
\text { (Competitive } \\
\text { Advantage) }\end{array}$ & $\begin{array}{l}\text { 3. Watching Place } \\
\text { 4. Relevancy to the Reality of the Film } \\
\text { 5. Educational Value of the Film } \\
\text { 6. Supervision of the Government }\end{array}$ \\
\hline $\begin{array}{l}\text { Third Factor } \\
\text { (Uniqueness) }\end{array}$ & $\begin{array}{l}\text { 7. Internal Environment of the Cinema } \\
\text { Hall } \\
\text { 8. Imitation of the Film } \\
\text { 9. Sound of the Film }\end{array}$ \\
\hline $\begin{array}{l}\text { Fourth Factor } \\
\text { (Support) }\end{array}$ & $\begin{array}{l}\text { 10. Resolution of the Film } \\
\text { 11. Song of the Film } \\
\text { 12. Role of the Sensor Board }\end{array}$ \\
\hline $\begin{array}{l}\text { Fifth Factor } \\
\text { (Feature) }\end{array}$ & $\begin{array}{l}\text { 13. Duration of the Film } \\
\text { 14. Story of the Film } \\
\text { 15. Dialogue of the Film } \\
\text { 16. Action of the Film } \\
\text { 17. Language of the Film }\end{array}$ \\
\hline $\begin{array}{l}\text { Sixth Factor } \\
\text { (Quality) }\end{array}$ & 18. Actor/ Actress of the Film \\
\hline
\end{tabular}

Table 6: Component Matrix (a)

\begin{tabular}{|l|c|c|c|c|c|c|}
\hline \multirow{2}{*}{ Variables } & \multicolumn{5}{c|}{ Factor } \\
\cline { 2 - 6 } & First & Second & Third & Fourth & Fifth & Sixth \\
\hline Duration of the Film & -.117 & .155 & .547 & .052 & .021 & .273 \\
\hline Story of the Film & .110 & .226 & .420 & -.071 & -.119 & .559 \\
\hline Dialogue of the Film & .004 & .052 & .454 & -.305 & .386 & .217 \\
\hline Resolution of the Film & -.017 & -.050 & .717 & -.003 & -.003 & -.397 \\
\hline Actor/ Actress of the Film & .065 & .149 & .024 & -.241 & .496 & -.571 \\
\hline Song of the Film & .020 & .107 & .668 & .174 & -.158 & -.312 \\
\hline Action of the Film & .100 & .134 & -.166 & -.205 & .637 & .223 \\
\hline Language of the Film & -.095 & -.039 & .485 & -.017 & .414 & .115 \\
\hline Role of the Sensor Board & -.060 & .016 & .393 & -.026 & -.366 & .005 \\
\hline Watching Place & -.387 & .592 & -.048 & .654 & .172 & -.005 \\
\hline Internal Environment of the Cinema Hall & .074 & .852 & -.020 & -.377 & -.191 & -.081 \\
\hline Competition of the Film Industry & .753 & .085 & .037 & .537 & .068 & .013 \\
\hline Imitation of the Film & .566 & .389 & -.051 & -.480 & -.176 & -.012 \\
\hline Relevancy to the Reality of the Film & -.437 & .660 & -.119 & .264 & .035 & .011 \\
\hline Educational Value of the Film & .025 & .909 & -.041 & .146 & .016 & -.036 \\
\hline Sound of the Film & .789 & .379 & -.051 & -.279 & -.048 & -.017 \\
\hline Location Selection of the Film & .808 & -.069 & .010 & .411 & .111 & .043 \\
\hline Supervision of the Government & -.923 & .142 & -.070 & -.209 & -.034 & .021 \\
\hline
\end{tabular}

Extraction Method: Principal Component Analysis.

(a) 6 components extracted. 


\section{First Factor: Convenient}

The first and most important factor is convenient constituted the variables; competition of the film industry and location selection of the film in the eyes of the general people. This factor constitutes only two variables, and both of the variables have factor loadings of more than 0.50 which clearly shows the relative strength of the individual variable. This factor is important because a) there are so many types of films (Kolkata Bangla Film,
Hindi Film, Tamil Film and English Film, etc.) are available in dish channel (satellite), b) due to latest technology, people also use internet and they download the films which save both cost and time too and c) the people neglects the cinema hall because of the poor tangible services and also for the reason of a far distance. That's why; the film producers and promoters have to highlight this factor to watch more Bengali films. Otherwise, the audiences do not watch Bengali films more.

Table 7: Rotated Component Matrix (a)

\begin{tabular}{|l|c|c|c|c|c|c|}
\hline \multicolumn{1}{|c|}{ Variables } & \multicolumn{5}{c|}{ Factor } \\
\cline { 2 - 6 } & First & Second & Third & Fourth & Fifth & Sixth \\
\hline Duration of the Film & -.038 & .149 & -.022 & .300 & .467 & -.288 \\
\hline Story of the Film & .064 & .061 & .230 & .111 & .437 & -.555 \\
\hline Dialogue of the Film & -.075 & -.104 & .107 & .039 & .684 & .029 \\
\hline Resolution of the Film & .017 & -.081 & -.051 & .727 & .292 & .226 \\
\hline Actor/ Actress of the Film & -.019 & .036 & .164 & .027 & .177 & .773 \\
\hline Song of the Film & .112 & .107 & -.011 & .744 & .172 & .053 \\
\hline Action of the Film & .056 & .054 & .103 & -.537 & .441 & .232 \\
\hline Language of the Film & .001 & .006 & -.173 & .137 & .613 & .077 \\
\hline Role of the Sensor Board & -.096 & -.052 & .069 & .458 & .024 & -.257 \\
\hline Watching Place & .023 & .947 & -.253 & .007 & .000 & .001 \\
\hline Internal Environment of the Cinema Hall & -.200 & .434 & .827 & .072 & -.004 & .023 \\
\hline Competition of the Film Industry & .921 & .119 & .051 & .031 & -.051 & -.036 \\
\hline Imitation of the Film & .175 & -.132 & .829 & -.036 & -.018 & .006 \\
\hline Relevancy to the Reality of the Film & -.251 & .802 & .036 & -.042 & -.034 & -.023 \\
\hline Educational Value of the Film & .063 & .789 & .472 & .017 & .024 & .026 \\
\hline Sound of the Film & .486 & -.089 & .772 & -.074 & .012 & .058 \\
\hline Location Selection of the Film & .911 & -.079 & .049 & -.045 & -.017 & -.013 \\
\hline Supervision of the Government & -.894 & .288 & -.198 & -.030 & .019 & -.021 \\
\hline
\end{tabular}

Extraction Method: Principal Component Analysis.

Rotation Method: Varimax with Kaiser Normalization.

(a) Rotation converged in 7 iterations.

\section{Second Factor: Competitive Advantage}

This factor constitutes watching the place, relevancy to the reality of the film, the educational value of the film and supervision of the government towards film industry where all of the variables have factor loadings of more than 0.50 except supervision of the government towards film industry which also shows the relative strength of the individual variable. According to the views of the general people, the government doesn't look after this industry promptly. So, to do well for the country with the help of this industry, the government also should have a good governance on the industry and subsidize if possible.

\section{Third Factor: Uniqueness}

This factor constitutes the internal environment of the cinema hall, imitation of the film and sound of the film where all of the variables have factor loadings of more than 0.50 which also shows the relative strength of the individual variable. The films produced in this country are not unique according to the peoples' view because they described that most of the Bengali films are copied from Tamil film and Kolkata Bengali film. Even the cinema halls are not properly decorated as the desire of the people, and the sound system is very poor. So, the Dhallywood industry should provide a good look at this factor otherwise, the audiences again do not watch films more.

\section{Fourth Factor: Support}

This factor constitutes the resolution of the film, song of the film and the role of the sensor board where all of the variables have factor loadings of more than 0.50 except role of the sensor board which also shows the relative strength of the individual variable. Most of the Bengali films today are produced following some western culture which is socially and culturally prohibited in Bangladesh. Even the films are also prohibited by the laws of our religious aspect. And all the reasons are the negligence of Bangladesh Sensor Board. Even the support services (video camera, cameramen, lyric person, etc.) that are highly required for producing a good film also won't consider in a well-manner. It may lack of proper financing and good governance of the government. Although, today there are some different programs from the government 
i.e. awards to the celebrity, subsidy to some films etc. to encourage the producers and celebrities to do well, but still it should be extended for performing well.

\section{Fifth Factor: Feature}

This factor constitutes duration of the film, story of the film, dialogue of the film, action of the film and language of the film where all of the variables have factor loadings of more than 0.50 except duration of the film, story of the film, and action of the film which also shows the relative strength of the individual variable. The story, duration and action of the film is not well considered when a film is produced, but the dialogue and the language of the film are mostly necessary for the attraction of the viewers. The people stated that some of the recent films (Hazar Bachar Dhore, Guerilla, Chorabali) are doing well but except these most of the films did a very low-quality films. The local necked language and the dialogue are not attached properly in the films. So, the director and producer should sincere about this subject matter. Though the people are somewhat satisfied regarding the story, duration and action of the films in Bangladesh, but it also should be improved for creating a good position in the current market competing with the other films from foreign industries in Bangladesh.

\section{Sixth Factor: Quality}

This factor constitutes an actor and actress of the film which has factor loadings of more than 0.50 which also shows the relative strength. Since most of the customers of the Bangladeshi films are the workers and rickshaw pullers, that's why they measure the quality of the films by the setup of the actor and actress. So, they said that the Bangla film should consider the popular actor and actress. The audiences sometimes make their arguments that most of the cases, today, it is seen that the celebrities are not welltrained and even expert. So, the producers, directors, and promoters should keep it mind about this factor very well.

\section{Conclusion AND Recommendations}

To represent a country in the world, it is important to develop its culture. Culture is mostly affected by the film because a story of film presents the nation's attitudes, values, beliefs and norms and the combinations of all its relevant variables make the film popular to the viewer and this popularity bring the success. So, to develop the culture, it is necessary to develop the condition of film industry so that the people show the positive attitude towards the Bengali film. In this regard the following recommendations may be necessary:

- The selection of dialogue, getup, language, sound, song, dance, action, resolution, culture, music and many more things are not appropriate with the Bengali film. So, the producer should improve the quality (all the determinants) of a film.
- The film that is produced in Bangladesh not applicable for all level of the people because producer is not conscious about their customer level and customer choice. So, they should keep their concentration on the educational value of the customer.

- The director always tries to follow western film and Hindi film which decreases the image of the Bengali film. So, it is needed to stop copying from other cultures like Tallywood and Hollywood movies.

- When producer produces a film at that time producers are not conscious about the society. Necked films (short dressed) are not socially acceptable. That's why, the directors should consider where the film should be promoted clearly that means they should focus on the target audience of the films.

- The story of the maximum Bengali film is the same to each other for which people are not interested to see all the films that are produced. As a result, the popularity of the Bengali film decreases day by day. So, it requires variation in the story investing in a good story based film.

- The people working in the film industry are not knowledgeable for making the film. Even they don't have any kind of institutional knowledge. So, they have to aware about institutional education related to making a film.

- The quality and qualification of maximum hero and heroine are not standard. That's why their acting doesn't express the reality. So, they should organize many reality shows to find out the qualified heroheroine like 'super hero-heroine' telecasted on NTV channel, 'Lux Channel i Superstar', telecasted on Channel $\mathrm{i}$ etc. Even the hero and heroine require education and good training.

- The instruments for producing a film are not modern technology based. For this reason the audience is not satisfied with this poor print. So, the government should provide some financial and technological support for producing a successful film.

\section{REFERENCES}

Ahmed, I. (2010). Entertainment or Exitainment?. First News, 24 October 2010, p. 39.

Biswas, S. (2013). Bangladeshis Take Bengalis Film Industry by Storm. India Today, August 19, 2013, available at http:/ /indiatoday.intoday.in/story/bangladeshis-takebengali-film-industry-by-storm/1/306628.html

Daily Prothom Alo. (2013). Entertainment, May 9, Retrieved from http:/ / epaper.prothomalo.com/view/dhaka/2014-11$04 / 16$

Hayat, A. (1987). History of Bangladesh Cinema (Dhaka: Bangladesh Film Development Corporation). p. 43-55.

Islam K. S. (2008). Epilogue. The Daily Star, $12^{\text {th }}$ May 2008 available http://www.thedailystar.net/beta2/news/epilogue/ 
Kabir, A. (1979). Film in Bangladesh (Dhaka: Bangla Academy). p. 22-24.

Lovelock, C, Wirtz, J \& Chatterjee, J. (2013), Service Marketing, 7th Ed. Delhi, Pearson Publishing.

Masud, C. (2011). Film Policy in Bangladesh: The Road to Reform, Forum, 5 (11), Transcraft ltd. Dhaka.

Masud, T. (2012). Chalachitrajatra (venture of Movies), Dhaka, Prothoma Prokashan.

Mutsuddi, C. (1987). Social Commitment in Bangladesh Cinema (Dhaka: Bangladesh Arts Academy). p. 19-22.

Quader, M.T. (1993). Bangladesh Film Industry (Dhaka: Bangla Academy). p. 96-97, 103-119.
Raju, Z. H. (2011). Bangladesh Cinema and National Identity: In Search of the Modern? London: Routledge. Ch. 5.

Raju, Z. H. (2012). Weak Father, Strong Mother and (In) visible Nation: Genre and Narrative in Bangladesh Popular Cinema. Forum-A Monthly Publication of The Daily Star. 6(12) available at http:/ / archive.thedailystar.net/forum/2012/December/w eak.html

Yeasmin, S. (2011). Contemporary Bangldeshi Commercial Cinema: A Perspective from Young Generation of Bangladesh, ASA Uniiversity Review, 5 (1), Dhaka.

Zaki. S. S. (1997). Bangladesh Cinema: A Brief Review. Celluloid 20.1 (December 1997) p.20-23.

\section{APPENDIX}

Communalities of the Variables

\begin{tabular}{|c|l|c|c|l|c|}
\hline $\begin{array}{c}\text { Variable } \\
\text { Code }\end{array}$ & Variable Name & Extraction & $\begin{array}{c}\text { Variable } \\
\text { Code }\end{array}$ & Variable Name & Extraction \\
\hline $\mathrm{V}_{1}$ & Duration of the Film & .415 & $\mathrm{~V}_{10}$ & Watching Place & .961 \\
\hline $\mathrm{V}_{2}$ & Story of the Film & .572 & $\mathrm{~V}_{11}$ & Internal Environment of the Cinema Hall & .918 \\
\hline $\mathrm{V}_{3}$ & Dialogue of the Film & .498 & $\mathrm{~V}_{12}$ & Competition of the Film Industry & .869 \\
\hline $\mathrm{V}_{4}$ & Resolution of the Film & .675 & $\mathrm{~V}_{13}$ & Imitation of the Film & .736 \\
\hline $\mathrm{V}_{5}$ & Actor/ Actress of the Film & .658 & $\mathrm{~V}_{14}$ & Relevancy to the Reality of the Film & .712 \\
\hline $\mathrm{V}_{6}$ & Song of the Film & .610 & $\mathrm{~V}_{15}$ & Educational Value of the Film & .852 \\
\hline $\mathrm{V}_{7}$ & Action of the Film & .554 & $\mathrm{~V}_{16}$ & Sound of the Film & .849 \\
\hline $\mathrm{V}_{8}$ & Language of the Film & .431 & $\mathrm{~V}_{17}$ & Location Selection of the Film & .842 \\
\hline $\mathrm{V}_{9}$ & Role of the Sensor Board & .293 & $\mathrm{~V}_{18}$ & Supervision of the Government & .923 \\
\hline
\end{tabular}

$--0-$ 
Online Archive: https://abc.us.org/ojs/index.php/abr/issue/archive 